UDC 338.439.52

DOI: $10.15673 /$ fie.v11i1.1294

\author{
Didukh S. \\ Ph.D., Associate Professor \\ Department of Industrial Economics \\ E-mail: didukhsm@i.ua \\ ORCID ID: 0000-0003-1534-0975 \\ Aoun V.
}

The student of the fourth grade of Economy, Business and Control Faculty

Odessa National Academy of Food Technologies

Kanatna str., 112, Odessa, Ukraine, 65039

E-mail: valeriaoun98@gmail.com

\title{
APPLICATION OF THE "BLUE OCEAN" STRATEGY IN UKRAINIAN WINEMAKING INDUSTRY
}

The research examines the nature and characteristics of the "blue ocean" strategy application in a highly competitive environment, the theoretically grounded the necessity and sequence of the implementation of the Blue Ocean Strategy in the wine industry of Ukraine

The paper proposes a new strategic channel for the wine industry in Ukraine based on a survey of 50 potential consumers of wine products, divided into 3 target groups. We have built the strategic outline for the winemaking market of Ukraine, identified key competitive factors and their significance. Based on the analysis, the directions for the implementation of the "blue ocean" strategy for wine producers were proposed: creation of a new innovative value for consumers, for which it is necessary to reject the traditional factors of competition and to strengthen only those that are of importance to the consumer: the localization of production and its naturalness; ease of choice; ease of perception of products.

Proposals for the creation of the "blue ocean" in the winemaking industry of Ukraine were presented: producers should discard the factors "oenological terminology" and "expenses for indirect marketing", weaken the factors "breadth of the assortment", "prestige of the winery" and "richness of taste".

The research presents an assessment of the effectiveness of the "blue ocean" strategy implementation using the example of the "Shabo" winemaking company based on the assessment of the attractiveness of the wine market and the assessment of the company competitiveness.

It is shown that the "blue ocean" strategy implementation will increase the level of the company competitiveness, and this strategy can be effective in the current market conditions.

Key words: "Blue Ocean" strategy, wine, winemaking industry, strategic outline, strategic curve, the DPM matrix, competitiveness.

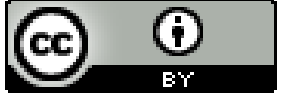

This work is licensed under a Creative Commons Attribution 4.0 International License http://creativecommons.org/licenses/by/4.0/
Statement of the problem and its connection with important scientific and practical tasks. Ukrainian winemaking industry has significant potential considering the climatic conditions, traditions of wine consumption and export opportunities. However, its potential at present time is not fully disclosed. Given the trends in the rapid development of the wine products' world market, increasing the percentage of wine consumption and competition from other winemaking countries, Ukrainian enterprises need to look for new markets in order to increase product sales, and to use their capacities as efficiently as possible.

Increasing competition requires companies to search for fundamentally new and more effective strategies. This is due to the fact that in the brutal struggle advertising costs increase dramatically, as well as costs for marketing and distribution. Although, final products do not much differ from each other. This situation can be changed using new approaches to capturing the consumers' attention.

One of such innovative approaches is the implementation of the "Blue Ocean" strategy. According to its basic principles, a company can avoid direct competition, which in turn will enable it to develop rapidly and generate high profits. Hence, today a topic of applying the "Blue Ocean" strategy in various industries, in particular in the winemaking industry of Ukraine, is relevant.

The analysis of the latest publications on the problem. The basics of this strategy were outlined in the book "The Blue Ocean Strategy" written by professors of strategic management of the world famous business school INSEAD - Chan Kim and Rene Moborn [1]. There are quite a lot of scientific works on management and economics devoted to the use of the "Blue Ocean" strategy and its effectiveness in various fields, but most of them describe already implemented strategic decisions. 
Forming of the aims of the research. The aim of this research is to study the possibilities of using the "blue ocean" strategy and proposing possible ways to create the "blue ocean" in the wine market of Ukraine.

The object of this research is marketing and trading activities of Ukrainian winemaking companies.

The subject of this research is features of the winemaking companies' activities to ensure the sale of products in modern conditions.

Key tasks of research are: to study the essence and characteristics of the use of the "blue ocean" strategy in conditions of high competition; to build a strategic outline of the winemaking industry of Ukraine; to develop proposals for creating the "blue ocean" in the winemaking industry of Ukraine; to evaluate the effectiveness of the "blue ocean" application.

To achieve this aim, the following methods of creating new "blue oceans" were used in research: a strategic outline and a four-action model.

Giving an account of the main results and their substantiation. Ukrainian wine market is highly competitive with a large number of players, where consumer choice is based on a large number of factors. In such a situation, it is impossible to conquer consumers only by low price or outstanding quality. In addition, consumer preferences are dynamically changing.

Most winemaking companies in Ukraine offer products with similar consumer properties which only slightly differ in price, taste and design. Such homogeneity of goods leads to increased competition without expanding the boundaries of the market. Such a situation in management is called the "red ocean" - an area that has already been formed and which is characterized by active competitive struggle.

"Red Oceans" are the important and integral part of the global market. However, when supply begins to exceed demand in a wide variety of industries, it is not enough to compete for market share in the formed market in order to maintain steady growth. In this case, the new strategy of "blue ocean" should be applied.

"Blue Ocean" is a market space where there is no competition. In other words, it is a temporarily created monopoly, however, created not by administrative levers, but by innovations and creativity [2]. The experience of the "blue ocean" strategy use has proven that it is effective in modern market conditions. The proof of this is the operation of companies that have demonstrated the effectiveness of this strategy, such as: Cirque du Soleil, McDonald's, Ford, Zara, FitCurves and others.

Most of the "blue oceans" are formed on the basis of "red oceans". Therefore, in order to create own "blue ocean" Chan Kim and Rene Moborn offer six basic principles (or options) that can be used separately and in any combination [1]:

1) changing the boundaries of existing markets or shifting attention to alternative markets;

2) focusing on consumers (not customers) who are not satisfied with the existing market segmentation;

3 ) studying of strategic groups of industries in order to create own strategy based on the preferences of potential customers;
4) provision of additional services and products;

5) focusing when creating the "blue ocean" on the emotional and functional attractiveness of the product;

6) searching for one or several trends that would play a decisive role in this business, have a clear trajectory and are irreversible.

In our opinion, Ukrainian winemakers have significant potential for development through the use of more effective marketing tools and the creation of new successful brands. For this purpose, it is advisable to use the concept of "blue ocean".

The world wine market is developing dynamically - in 2017 the value of the world wine market could be estimated at $\$ 302.02$ billion USD dollars. Experts predict that by 2023 this figure will increase by $14 \%$ and will be approximately estimated as 427.6 billion USD dollars [5]. What's more, analysts predict that by 2021 alcohol consumption in the world will grow by $0.8 \%$. The segment of sparkling wines, whiskey and cocktails is expecting rapid growth, as this is confirmed by the growing demand from consumers of these types of products.

At the present stage of development Ukrainian wine market is characterized by the lack of positive growth dynamics since there are quite a lot of obstacles that create problems in the efficient and stable operation of Ukrainian winemaking companies. Among them such problems could be mentioned: lack of support from the government, low quality and high price of products, high competition, difficult political situation, insecurity of local producers, high license prices, low availability of raw materials, corruption etc.

Nowadays there are two main winemaking centers in Ukraine: the Black Sea Coast (Odessa, Kherson and Nikolayev regions) and Trans-Carpathian region. This centers have been formed due to the location and climate. The largest volume of wine production falls on the Odessa region $-61.5 \%$. Nikolayev region occupies second place (12.7\%). Kherson (10\%) and TransCarpathian $(9.5 \%)$ regions occupy the third and fourth place respectively. Table 1 shows the production dynamics of the main types of wine products over the past six years.

In our opinion, Ukrainian winemaking is in crisis from the point of view of finding its own identity. Local wines are on average inferior to imported wines in quality and taste with a slight difference in price.

After reviewing the situation on the market, we can begin to build a strategic outline of the market. The strategic outline of the market is a simplified market model, which is presented in the form of a graph, and it is possible to reveal the similarity and distinction of its own strategy from the strategies of competitors.

Unlike the market development strategy, the strategic outline is an instrument for diagnosing and building an exciting blue ocean strategy. It performs two tasks: it reflects the current state of affairs in the market, which makes it possible to understand where competitors are investing and describes products that are subject to competition within the industry. 
Table 1

Dynamics of wine products production in Ukraine by type [4]

\begin{tabular}{|c|c|c|c|c|c|c|}
\hline \multirow{2}{*}{ Products title according to the nomenclature of industrial production } & \multicolumn{6}{|c|}{ Produced per year } \\
\hline & 2012 & 2013 & 2014 & 2015 & 2016 & 2017 \\
\hline Liqueurs and other spirits, mln.dal & 11,5 & 11,5 & 10,4 & 8,7 & 5,3 & 6,2 \\
\hline Sparkling wine "Champagne of Ukraine", mln.dal & 3,3 & 3,1 & 2,6 & 3,2 & 3 & 2,1 \\
\hline Wine with an actual alcohol concentration of no more than $15 \%$, mln.dal & 8,6 & 7,3 & 4,7 & 6,7 & 6,1 & 6,7 \\
\hline
\end{tabular}

To build the strategic outline, it is necessary to build a value curve that is the main component of the strategic outline, and is a graphic image of the company's comparative efficiency, taking into account the competitive factors of the industry [1]. Let us single out the following factors of the wine choice in Ukraine [3]: cost of a bottle of wine; quality of wine aging; prestige of a winery and its history (with the indication of a company age); richness and refinement of taste; oenological terminology (noble type of packaging, label with a list of medals and awards); assortment; indirect marketing.
In accordance with this, a survey of 50 potential consumers of wine products divided into 3 groups "Students", "Office Qualified Workers" and "Married Couples" - was conducted. The survey was conducted separately for two groups of wines: "Inexpensive wines" (up to $120 \mathrm{UAH}$ for a bottle of 0.7 l) and "Expensive wines" (more than $120 \mathrm{UAH}$ for a bottle of 0.7 1). Based on a study of the wine market and the survey conducted, the strategic outline of Ukrainian wine market was constructed (Fig. 1).

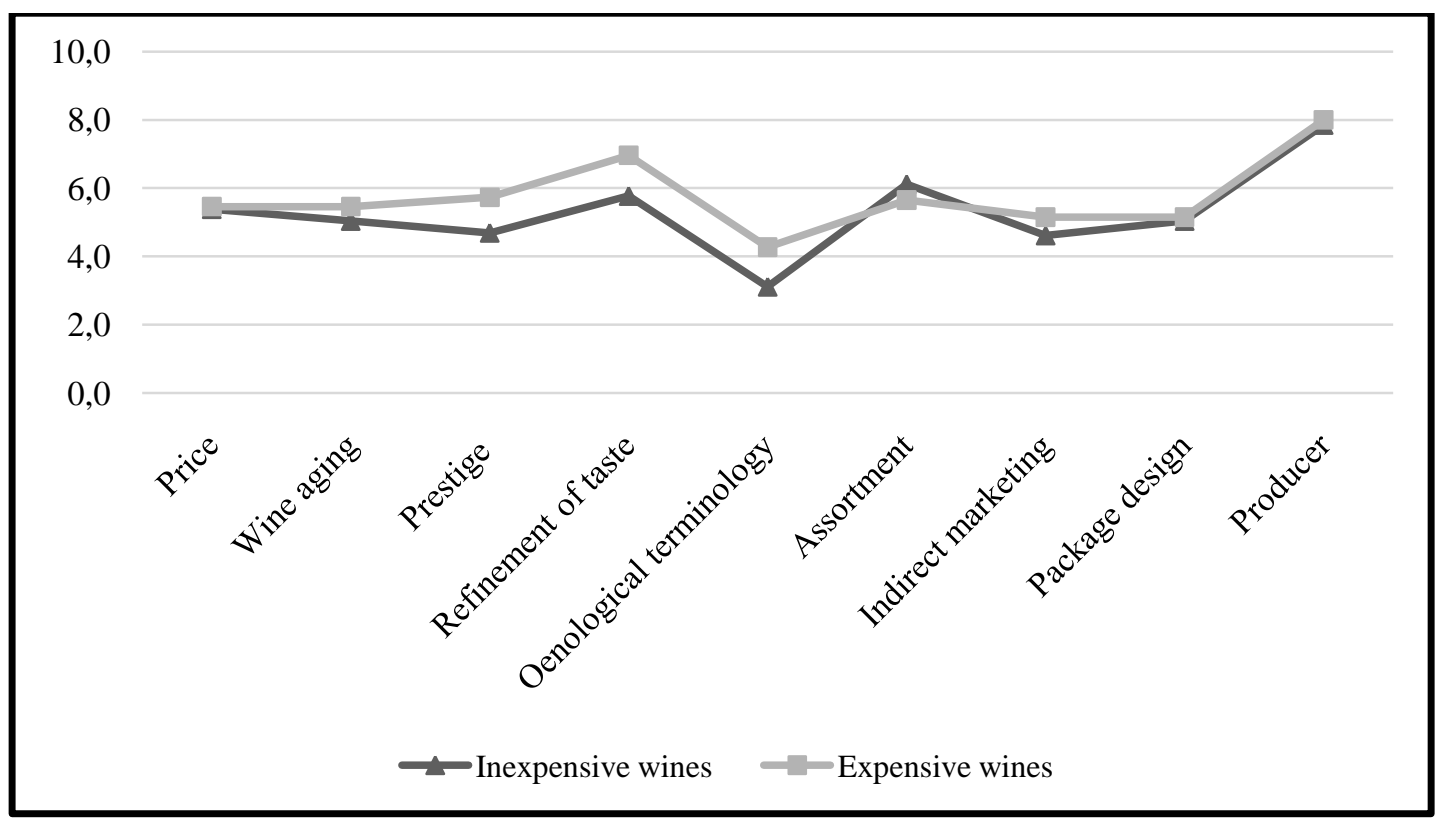

Fig.1. The strategic outline of Ukrainian wine market *

*author's development

As can be seen, the value curves of two groups of wines are very similar. The main factors in the choice of wine according to the results of the consumer survey are taste, quality and a proven producer. At the same time, the factors underlying the strategies of vast majority of producers, such as assortment and prestige of the producer, were less important to consumers.

Thus, we have built the strategic outline of the wine market and identified key criteria for the selection of wine by consumers, as well as the main criteria for the strategic positioning of producers.

After analyzing the results, we can propose to expand the boundaries of an existing market. To do this, we have built a new value curve in order to understand what exactly we need to change. For its construction, the model of four actions was used. The first two steps will help reduce costs. The other two will help to create new value for consumers and create new demand.

In order to create the effective "blue ocean" strategy, it is necessary to answer the key questions: "What does the consumer want?" and "What could be the new significant competitive advantages?".

The global trend is the consumption of local authentic products, author's local wines and other beverages. Analysis of world experience shows that those new wine-making countries (Chile, Georgia) and trademarks ("Kolonist"), which emphasize naturalness and authenticity of products, achieve success. What competitive advantage does Ukrainian wine have over wines from leading winemaking countries? It is the locality and naturalness 
of local wines.

So, having analyzed the current strategic outline of the winemaking industry of Ukraine, the four-action model will look like on Fig. 2.

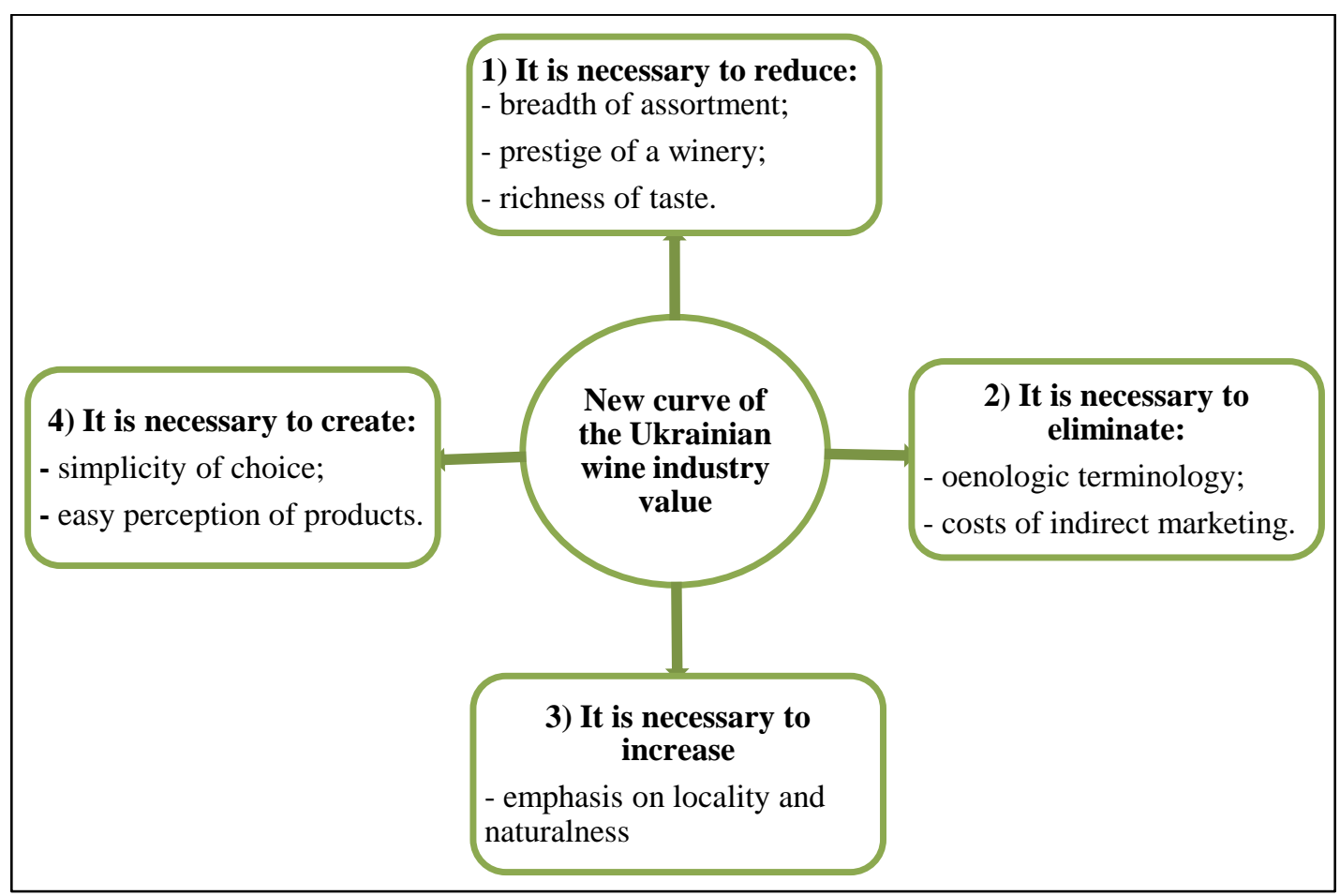

Fig.2. New strategic curve of the Ukrainian wine industry value *

*author's development

The second thing that can be proposed for the wine industry in Ukraine is not to focus on competitors, but to focus on non-customers, they will help create a new demand. Non-customers in this area include people who consume alcohol (for example, various cocktails, beer, vodka etc.), but not wine. Therefore, it is necessary to create such a wine drink that would be able to combine a group of potential consumers and a group of noncustomers.

In our opinion, it is necessary to create new factors of choice, such as:

- locality of products and its naturalness;

- ease of choice;

- ease of products perception.

It is advisable to reduce the importance of such factors of choice as the assortment breadth, the taste richness and prestige of a winery. In our opinion, the consumer wants a simpler choice among a small number of simple and clear products. The product must be light, pleasant to the taste, and for its consumption you do not need to be an expert.

We recommend eliminating such factors as:

- oenological terminology and indirect marketing: remove complex oenological terminology from labels and name the product simply so that it is easily re- membered. The label should be clear and demonstrate the simplicity and availability of wine;

- excessive quality of aging. Reducing the assortment of wines of several types and reducing the duration of aging will reduce the cost of a company.

Now, based on the model of four actions, we can build a new outline of the wine industry in Ukraine. On the new strategic outline (Fig. 3) the new value curve is different from the others. This is because we did not focus on competitors, but instead decided to consider alternative options.

It should also be noted that in order the "blue ocean" strategy to be efficient, simple and effective, there are three additional factors to follow [1]: focus, divergence and attractive slogan.

In order to understand the possible consequences of implementing the strategy, we must evaluate it. We will evaluate it in three stages:

- first we build the managed policy matrix or DPM (Direct Policy Matrix). This will help us to find out the competitive opportunities for companies and the prospects for the profitability of Ukrainian wine market;

- the second stage will be the calculation of the costs of implementing the strategy;

- the final stage will be the calculation of the strategy effectiveness [8]. 


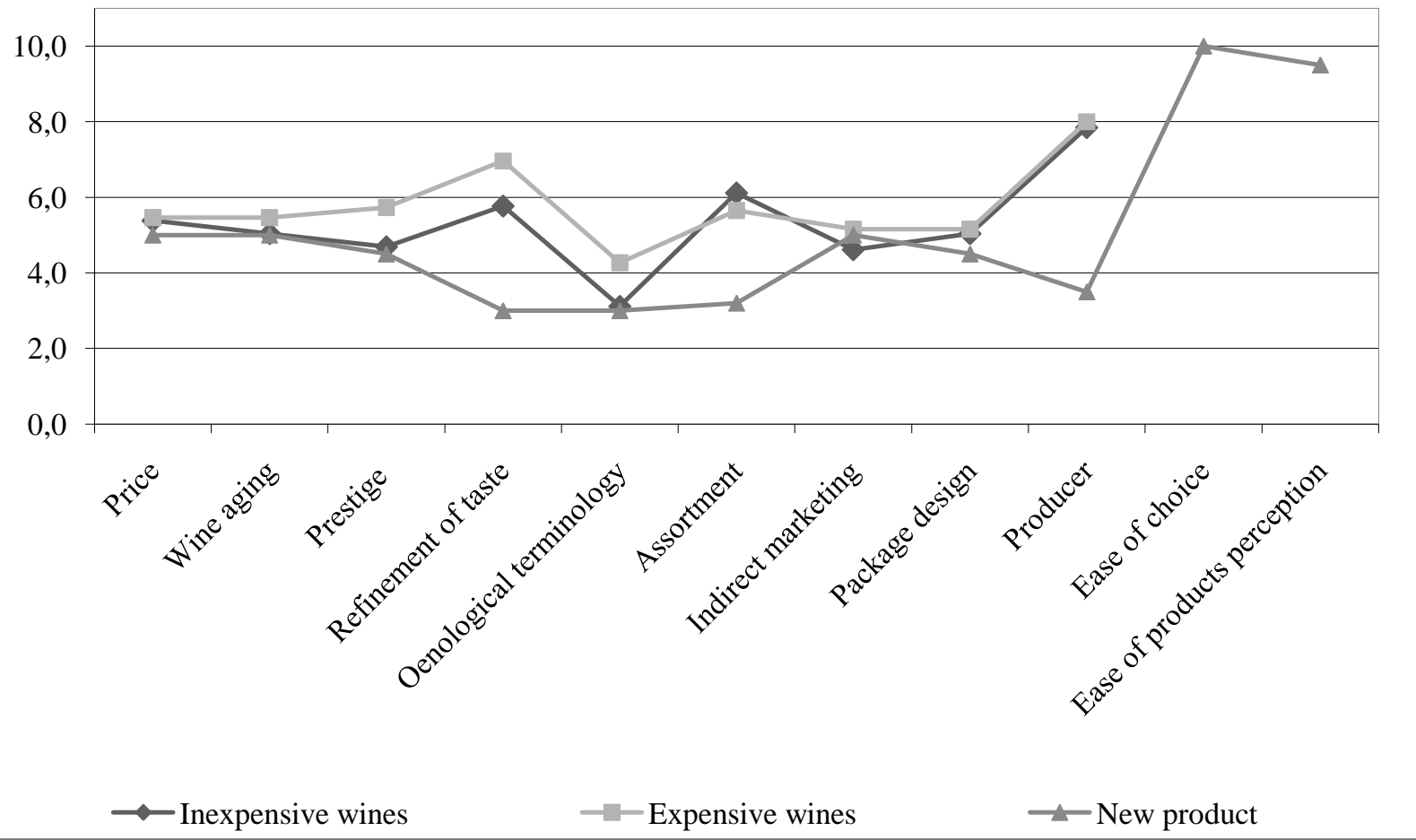

Fig. 3. New strategic outline of Ukrainian wine market*

*author's development

So, let us start from building the managed policy matrix. To assess the attractiveness of Ukrainian wine market, we used the following factors: the wine market size; market growth rates; financial ability of consumers; the nature of demand for products; intensity of competition within the market.

Table 2

\section{Expert assessment of the Ukrainian wine market attractiveness*}

\begin{tabular}{|c|c|c|c|c|c|c|c|c|}
\hline \multirow[b]{2}{*}{ Criteria } & \multirow[b]{2}{*}{$\begin{array}{l}\text { Weight } \\
\text { factor }\end{array}$} & \multicolumn{3}{|c|}{ Range of grades } & \multicolumn{2}{|c|}{ Current grades } & \multicolumn{2}{|c|}{ Perspective grades } \\
\hline & & low $\quad 0-3$ & $\begin{array}{l}\text { medium } \\
3-6,5\end{array}$ & $\begin{array}{l}\text { high } \\
6,5-10\end{array}$ & $\begin{array}{c}\text { Grades } \\
\text { from } 0 \\
\text { to } 10 \\
\end{array}$ & $\begin{array}{c}\text { Weighted } \\
\text { grade }\end{array}$ & $\begin{array}{c}\text { Grades } \\
\text { from } 0 \\
\text { to } 10 \\
\end{array}$ & $\begin{array}{l}\text { Weighted } \\
\text { grade }\end{array}$ \\
\hline $\begin{array}{l}\text { size of the wine } \\
\text { market }\end{array}$ & 0,3 & $<5 \%$ & $5-17 \%$ & $>15 \%$ & 4 & 1,2 & 7 & 2,1 \\
\hline $\begin{array}{l}\text { growth rate of the } \\
\text { market }\end{array}$ & 0,2 & low $<6 \%$ & $\begin{array}{c}\text { medium } \\
6-20 \% \\
\end{array}$ & $\begin{array}{c}\text { high } \\
>20 \% \\
\end{array}$ & 5 & 1 & 6 & 1,2 \\
\hline $\begin{array}{l}\text { financial capability } \\
\text { of consumers }\end{array}$ & 0,2 & low & medium & high & 6 & 1,2 & 8 & 1,6 \\
\hline $\begin{array}{l}\text { nature of demand } \\
\text { for products }\end{array}$ & 0,1 & decreasing & stable & $\begin{array}{c}\text { increas- } \\
\text { ing }\end{array}$ & 5 & 0,5 & 7 & 0,7 \\
\hline $\begin{array}{l}\text { intensity of compe- } \\
\text { tition in the middle } \\
\text { of the market }\end{array}$ & 0,2 & $\begin{array}{c}>7 \\
\text { competitors }\end{array}$ & $\begin{array}{c}3-7 \\
\text { competitor } \\
\text { s } \\
\end{array}$ & $\begin{array}{c}<3 \\
\text { competit } \\
\text { ors } \\
\end{array}$ & 5 & 1 & 3 & 0,6 \\
\hline Total & 1 & & & & & 4,9 & & 6,2 \\
\hline
\end{tabular}

*author's development

To determine the indicators of competitiveness, we select the "Shabo" company and evaluate its strengths and weaknesses by the following criteria: the degree of brand loyalty; product price; product quality; complete- ness and breadth of product selection; production capabilities. In table 3 final grades that reflect the current and future position of the company in the market (after the implementation of the "blue ocean" strategy) can be seen. 
Table 3

Assessment of the competitiveness of "Shabo" company *

\begin{tabular}{|c|c|c|c|c|c|c|c|c|}
\hline \multirow[b]{2}{*}{ Criteria } & \multirow{2}{*}{$\begin{array}{l}\text { Weight } \\
\text { factor }\end{array}$} & \multicolumn{3}{|c|}{ Range of grades } & \multicolumn{2}{|c|}{ Current grades } & \multicolumn{2}{|c|}{ Perspective grades } \\
\hline & & $\begin{array}{l}\text { low } \\
0-3\end{array}$ & $\begin{array}{l}\text { medium } \\
3-6,5\end{array}$ & $\begin{array}{c}\text { high } \\
6,5-10\end{array}$ & $0-10$ & Weighted & $0-10$ & Weighted \\
\hline $\begin{array}{l}\text { degree of commitment to } \\
\text { the brand }\end{array}$ & 0,15 & low & medium & high & 7 & 1,05 & 9 & 1,35 \\
\hline product price & 0,3 & low & medium & high & 4,5 & 1,35 & 4 & 1,2 \\
\hline product quality & 0,2 & low & medium & high & 7 & 1,4 & 8 & 1,6 \\
\hline $\begin{array}{l}\text { completeness and } \\
\text { breadth of products' } \\
\text { choice }\end{array}$ & 0,15 & low & medium & high & 4 & 0,6 & 6,5 & 0,98 \\
\hline production capacity & 0,2 & low & medium & high & 7 & 1,4 & 9 & 1,8 \\
\hline Total & 1 & & & & & 5,8 & & 6,93 \\
\hline
\end{tabular}

*author's development

Now, based on this data we can build the managed policy matrix. The DPM matrix for "Shabo" is shown in Fig. 4.
Having analyzed the built matrix, we can conclude that Ukrainian wine market is growing and attractive. "Shabo" has an average level of competitiveness on it.

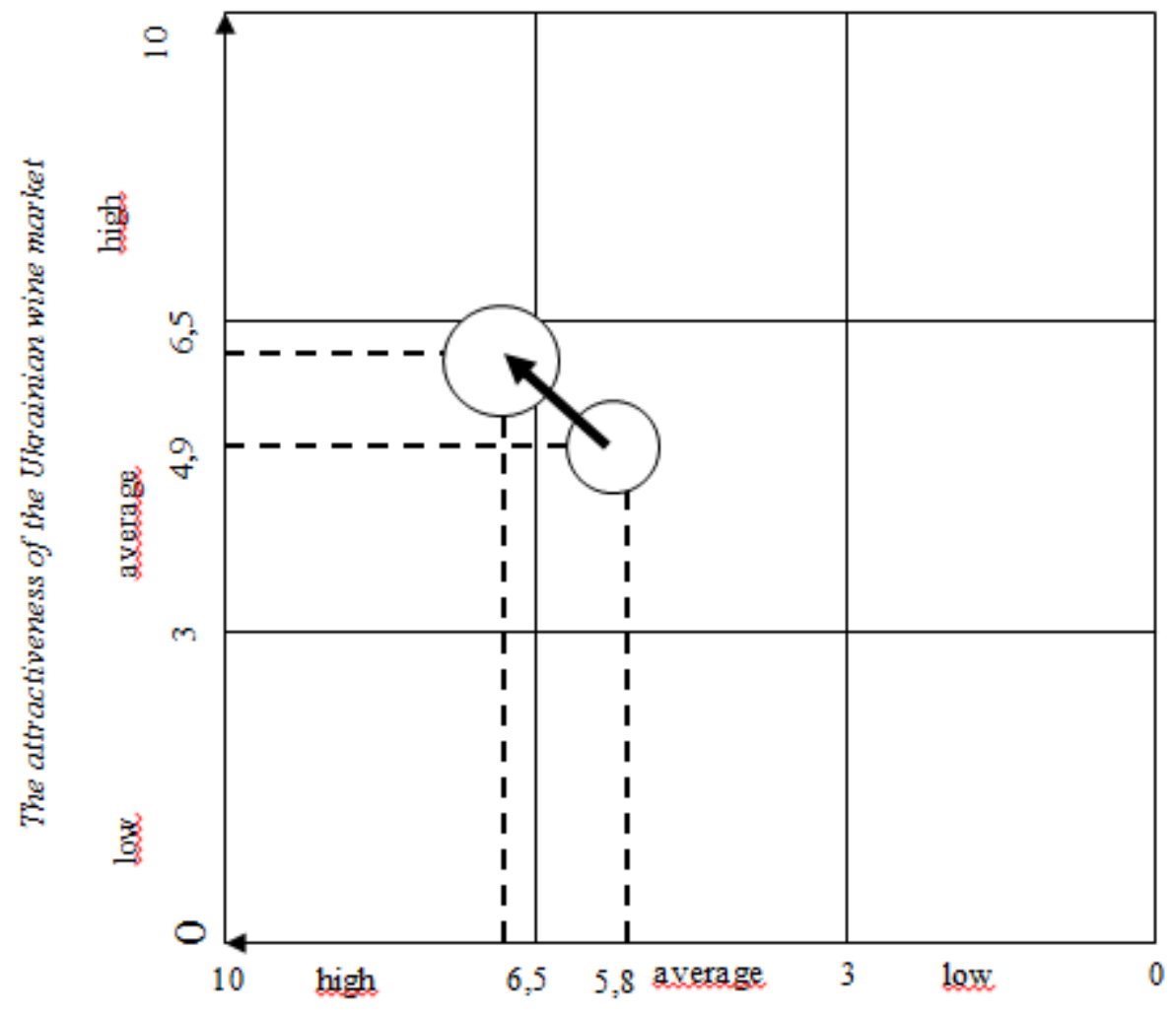

Competitiveness of Shabe Company in the Urainian wine market

Fig. 4. The DPM matrix for "Shabo"*

*author's development

Next, to assess the effectiveness of the strategy, we determine the costs for its implementation (Table 4). The final stage is the calculation of the strategy effective- ness. We will calculate it according to the following formula:

$$
\text { Strategy effectiveness }=\frac{\Delta \text { Competitiveness }}{\text { Costs for the implementation of the strategy }} * 100 \%
$$


Table 4

Costs for the implementation of the "blue ocean" strategy

\begin{tabular}{|c|c|}
\hline Costs & Cost, thousand dollars USA \\
\hline Research costs & 5 \\
\hline Product development costs & 12 \\
\hline Advertising costs & 18 \\
\hline Costs associated with the organization & 11 \\
\hline Other expenses & 5 \\
\hline Total & 51 \\
\hline
\end{tabular}

*author's development

In this formula we use the company competitiveness, since the company does not have the ability to influence on the market attractiveness. Therefore, for the calculation we use the difference in the grades of competitiveness and the costs for the implementation of the strategy:

$$
\text { Strategy effectiveness }=\frac{6,93-5,8}{61} * 100 \%=2,22 \%
$$

So, each thousand dollars spent on the implementation of the strategy will increase the company competitiveness by $2.22 \%$ that proves the effectiveness of the "blue ocean" strategy.

Conclusions and prospects of the further investigations. The research examines the nature and characteristics of the "blue ocean" strategy application in a highly competitive environment. The wine market is characterized by moderate growth rates with increased competition and the growing role of imported wines. That is to say that in current conditions the wine industry is a classic "red ocean" with a large number of players, a high level of competition and standard marketing strategies. In this environment Ukrainian winemakers have significant development potential due to the implementation of the "blue ocean" strategy - the creation of a new market where there is almost no competition.

We have built the strategic outline for the winemaking market of Ukraine, identified key competitive factors and their significance. Based on the analysis, the directions for the implementation of the "blue ocean" strategy for wine producers were proposed. They are: creating new innovative value for consumers, for which it is necessary to discard the traditional factors of competition and strengthen only those that matter to the consumer.

Proposals for the creation of the "blue ocean" in the winemaking industry of Ukraine were presented: producers should discard the factors "oenological terminology" and "expenses for indirect marketing", weaken the factors "breadth of the assortment", "prestige of the winery" and "richness of taste". It is possible to attract consumers by increasing the factor "locality and naturalness" and creating the factors "simplicity" and "lightness". Hence, the "blue ocean" in the wine industry is a simple, light, natural wine (several wines in the line). The brand emphasizes the origin of a particular region with an emphasis on the locality of this product.
The research presents an assessment of the effectiveness of the "blue ocean" strategy implementation using the example of the "Shabo" winemaking company based on the assessment of the attractiveness of the wine market and the assessment of the company competitiveness. It is shown that the "blue ocean" strategy implementation will increase the level of the company competitiveness, and this strategy can be effective in the current market conditions.

The scientific novelty, the theoretical and practical significance of the study is as follows:

- the necessity and sequence of implementation of the "blue ocean" strategy in the wine-growing industry of Ukraine in the conditions of high competition is theoretically grounded;

- a new strategic outline for the wine industry of Ukraine was proposed based on a survey of 50 potential consumers of wine products, divided into 3 target groups;

- a new curve of the value of the wine industry of

Ukraine is presented based on an analysis of its state and development prospects;

- recommendations for winemaking enterprises have been developed and concrete practical steps have been proposed to implement the blue ocean strategy in the wine industry on the basis of an improved strategic market strategy;

- the effectiveness of the implementation of the blue ocean strategy is proved on the example of the wineries "Shabo".

The prospects for further research are the development of a detailed blueprint plan for the Blue Ocean in the Ukrainian wine sector and, for example, individual enterprises, the definition of the blue ocean strategy in the face of high competition for other food and beverage industries, developing a model for assessing the effectiveness of the implementation. the blue ocean strategy. 


\section{References}

1. Kim, W. S., \& Mauborgne, R. (2005). Blue Ocean Strategy: How to Create Uncontested Market Space and Make the Competition Irrelevant. Boston: Harvard Business School Press.

2. Diachenko, T., \& Olshevska, L. (2015). Stratehiia «blakytnoho okeanu» yak novyi pidkhid u dosiahnenni konkurentnykh pozytsii. In Aktualni problemy menedzhmentu ta marketynhu v XXI st.(pp. 58-60). Zhytomyr.

3. Starostina, A. O. (1999). Metodolohiia i praktyka marketynhovykh doslidzhen v Ukraini (Doctoral dissertation, KNU im. Tarasa Shevchenka, 1999) (pp. 1-376). Kyiv: KNU im. Tarasa Shevchenka.

4. Derzhavna sluzhba statystyky Ukrainy. Retrieved December 01, 2018, from http://www.ukrstat.gov.ua

5. Za piat rokiv svitovyi rynok vyna zroste na $130 \mathrm{mlrd}$ dolariv (prohnoz). (2018, June 04). Retrieved December 01, 2018, from https://news.finance.ua/ua/news/-/427473/za-pyat-rokiv-svitovyj-rynok-vyna-zroste-na-130-mlrddolariv-prognoz

6. Ukrainske vynorobstvo: U bytvi za vyzhyvannia. (2017, October 26). Retrieved December 01, 2018, from https://www.epravda.com.ua/publications/2017/10/26/630499/

7. Ofitsiinyi sait hrupy «Shato Hrona». Retrieved December 01, 2018, from http://uk.wine.odessa.ua

8. Kochkina, N., \& Medvedieva, I. (2015). Otsinka efektyvnosti stratehii blakytnoho okeanu dlia vynorobnoi haluzi Ukrainy. Visnyk Kyivskoho Natsionalnoho Universytetu Imeni Tarasa Shevchenka. Ekonomika., 1(8), $25-31$.

9. Kotler, P. (2002). Marketing Management (11th ed.). Prentice Hall. doi:10.2307/12504

10. Lambin, J. J. (2007). Market-Driven Management: Strategic and Operational Marketing (2nd ed.). Palgrave Macmillan.

11. Generic Business Strategies, Organizational Context and Performance: An Empirical Investigation. (1986). Strategic Management Journal, (7), 217-231.

12. Official site Blue ocean strategy. Retrieved December 02, 2018, from https://www.blueoceanstrategy.com/

13. Aaker, D. A., \& Mcloughlin, D. (2009). Strategic Market Management: Global Perspectives. John Wiley \& Sons.

Received 29 January 2019

Approved 12 February 2019

Available in Internet 19.03.2019

\section{Дидух С.M.}

кандидат экономических наук, доцент кафедра экономики промышленности

E-mail: didukhsm@i.ua

ORCID ID: 0000-0003-1534-0975

Аун В.H.

студентка 4 курса фракультета экономики, бизнеса и контроля

Одесская национальная академия пищевых технологий

ул. Канатная, 112, м. Одеса, Украина, 65039

E-mail: valeriaoun98@gmail.com

\section{ПРИМЕНЕНИЕ СТРАТЕГИИ «ГОЛУБОГО ОКЕАНА» В ВИНОДЕЛЬЧЕСКОЙ ОТРАСЛИ УКРАИНЫ}

В работе исследована сущность и особенности применения стратегии «голубого океана» в условиях высокой конкуренции, теоретически обоснована необходимость и последовательность внедрения стратегии «голубого океана» в винодельческой отрасли Украины в условиях высокой конкуренции;

В работе предложена новая стратегическая канву винодельческой отрасли Украины на основе опроса 50 потенциальных потребителей винной продукции, разделенных на 3 целевых группы.

Построена стратегическая канва для винодельческого рынка Украины, выявлены ключевые фракторы конкуренции и их значимость. На основе проведенного анализа предложены направления внедрения стратегии «голубого океана» для производителей вина создание новой инновационной ценности для потребителей, для чего необходимо отбросить традиционные факторы конкуренции и усилить только те, которые имеют значение для потребителя: локальность продукции и ее натуральность; простота выбора; легкость восприятия продукции.

Построена новая кривая ценности винодельческой отрасли Украины на основе анализа ее состояния и перспектив развития. Представлены предложения по созданию «голубого океана» в винодельческой отрасли Украины: производителям следует отбросить факторы «энологичная терминология» и «расходы на косвенный маркетинг», ослабить фракторы «широта ассортимента», «престиж винодельни» и «богатство вкуса». В работе представлена оценка эфрфективности внедрения стратегии 
«голубого океана» на примере винодельческой компании «Шабо» на основе оценки привлекательности рынка вина и оценки конкурентоспособности предприятия.

Разработаны рекомендации для винодельческих предприятий и предложены конкретные практические шаги по внедрению стратегии «голубого океана» в винодельческой отрасли на основе усовершенствованной стратегической канвы рынка. Доказана эфрфективность внедрения стратегии «голубого океана» на примере винодельческой компании «Шабо».

Показано, что внедрение стратегии «голубого океана» позволит повысить уровень конкурентоспособности предприятия и данная стратегия может быть эффективной в текущих рыночных условиях.

Ключевые слова: стратегия «голубого океана», вино, винодельческая промышленность, стратегическая канва, кривая ценностей, матрица DPM, конкурентоспособность.

\section{Дідух C.M.}

кандидат економічних наук, доцент кафедра економіки промисловості

E-mail: didukhsm@i.ua

ORCID ID: 0000-0003-1534-0975

Аун B.M.

Студентка 4 курсу фракультету економіки, бізнесу і контролю

Одеська національна академія харчових технологій

вул. Канатна, 112, м. Одеса, Україна, 65039

E-mail:valeriaoun98@gmail.com

\section{ЗАСТОСУВАННЯ СТРАТЕГІЇ «БЛАКИТНОГО ОКЕАНУ» У ВИНОРОБНІЙ ГАЛУЗІ УКРАЇНИ}

У роботі досліджено сутність та особливості застосування стратегії «блакитного океану» в умовах високої конкуренції, теоретично обґрунтовано необхідність і послідовність впровадження стратегії «Блакитного Океану» у виноробній галузі України в умовах високої конкуренції.

У роботі запропонована нова стратегічна канву виноробної галузі України на основі опитування 50 потенційних споживачів винної продукції, розділених на 3 цільових групи. Побудована стратегічна канва для виноробного ринку України, виявлені ключові фактори конкуренції та їх значимість. На основі проведеного аналізу запропоновано напрями впровадження стратегії «блакитного океану» для виробників вина: створення нової інноваційної цінності для споживачів, для чого необхідно відкинути традиційні фрактори конкуренції та посилити тільки ті, що мають значення для споживача: локальність продукції і її натуральність; простота вибору; легкість сприйняття продукції.

Побудовано нову крива цінності виноробної галузі України на основі аналізу її стану та перспектив розвитку. Представлено пропозиції щодо створення «блакитного океану» у виноробній галузі України: виробникам слід відкинути фактори «енологічна термінологія» та «витрати на непрямий маркетинг», послабити фактори «широта асортименту», «престиж виноробні» та «багатство смаку».

Розроблено рекомендації для виноробних підприємств та запропоновано конкретні практичні кроки по впровадженню стратегії «блакитного океану» у виноробній галузі на основі удосконаленої стратегічної канви ринку. Доведено ефрективність впровадження стратегії «блакитного океану» на прикладі виноробної компанії «Шабо».

Показано, що впровадження стратегії «блакитного океану» дозволить підвищити рівень конкурентоспроможності підприємства і дана стратегія може бути ефективною в поточних ринкових умовах.

Ключові слова: стратегія "блакитного океану", вино, виноробна промисловість, стратегічна канва, крива цінностей, матриця DPM, конкурентоспроможність.

\section{Література}

1. Kim, W.C., Mauborgne, R. Blue Ocean Strategy: How to Create Uncontested Market Space and Make the Competition Irrelevant. Boston: Harvard Business School Press, 2005. 256 p.

2. Дяченко Т., Ольшевська Л. Стратегія «блакитного океану» як новий підхід у досягненні конкурентних позицій // Актуальні проблеми менеджменту та маркетингу в XXI ст.: матеріали VI міжвузівської студентської науково-практичної інтернет-конференції, 02 червня 2015p. С. 58-60. 
3. Старостіна А.О. Методологія і практика маркетингових досліджень в Україні: дис. на здобуття наук. ступеня д-р екон. наук: 08.06.02: захист 08.04.1999 / наук. кер. Д. М. Черваньов. Київ: КНУ ім. Тараса Шевченка, 1999. 376 с.

4. Державна служба статистики України: [Веб-сайт]. 2018. URL: http://www.ukrstat.gov.ua (дата звернення: 01.12.2018)

5. За п'ять років світовий ринок вина зросте на 130 млрд доларів (прогноз) // Finance.ua: [веб-сайт]. 2018. URL: https://news.finance.ua/ua/news/-/427473/za-pyat-rokiv-svitovyj-rynok-vyna-zroste-na-130-mlrd-dolarivprognoz (дата звернення: 01.12.2018).

6. Українське виноробство: у битві за виживання // Економічна правда: [Веб-сайт]. 2017. URL: https://www.epravda.com.ua/publications/2017/10/26/630499/ (дата звернення: 01.12.2018). 01.12.2018)

7. Офіційний сайт групи «Шато Грона»: [Веб-сайт]. 2018. URL: http://uk.wine.odessa.ua (дата звернення:

8. Кочкіна Н., Медведєва І. Оцінка ефективності стратегії блакитного океану для виноробної галузі України // Вісник Київського національного університету імені Тараса Шевченка. Економіка. 2015. Т. 1, вип. 8. C. 25-31.

9. Kotler P. Marketing Management. Prentice Hall; 11 ed., 2002. - 768 p. DOI: 10.2307/12504 2007. 496 p.

10. Lambin J.-J. Market-Driven Management: Strategic and Operational Marketing. Palgrave Macmillan; 2nd edition,

11. «Generic Business Strategies, Organizational Context and Performance: An Empirical Investigation» // Strategic Management Journal . 1986. No. 7. P. 217-231. 02.12.2018).

12. Official site Blue ocean strategy: [Website]. 2018. URL: https://www.blueoceanstrategy.com/ (viewed on:

13. Aaker D.A., Mcloughlin D. Strategic Market Management: Global Perspectives. John Wiley \& Sons, 2009. 354 p.

Стаття надійшла 29.01.2019

Стаття прийнята до друку 12.02.2019

Доступно в мережі Internet 19.03.2019

Цитування згідно ДСТУ 8302:2015

Didukh S., Aoun V. Application of the "Blue Ocean" strategy in Ukrainian winemaking industry // Food Industry Economics. 2019.

Vol.11, Issue 1. P. 49-58; doi: 10.15673/fie.v11i1.1294

Cite as APA style citation

Didukh S., \& Aoun V. (2019). Application of the "Blue Ocean" strategy in Ukrainian winemaking industry. Food Industry Economics, 11(1), 49-58 ; doi: 10.15673/fie.v11i1.1294 